\title{
Suggestive power of the word in the information space for sustainable development
}

\author{
Olga Nikolenko ${ }^{1, *}$ \\ ${ }^{1}$ Don State Technical University, Gagarin Square, 1. Rostov-on-Don, 344003, Russia
}

\begin{abstract}
The article reveals the problem of the status of suggestive texts, which is relevant for modern psycho-linguistics, determines their functional capabilities that allow them to participate in the structuring of speech images and convey subjective intentions through speech. The author proves that prayers, conspiracies, neurolinguistic programming and affirmations, increasing the emotionality of speech, play a special role in the implementation of the pragmatic goals of communication, since they contain a volume of suggestion that is much greater than in the options without them. All this explains the use of the designated units both in the media and in personality improvement courses: thanks to these formal shells, the author focuses the attention of his recipients on the key points of the message. Due to intentionality, suggestive statements act as a means of objectifying the worldview of their addressee. The aim of this study is to strive to comprehensively describe the texts of a suggestive orientation with an emphasis on their linguistic potential. In this regard, a significant role in achieving the set goals is assigned to the comparative characteristics of phono-lexico-syntactic units in prayers, conspiracies, texts of neurolinguistic programming and affirmations.
\end{abstract}

\section{Introduction}

The universal and significant role of verbal programming in human life demanded linguistic analysis and forced language scholars to turn to the study and description of this phenomenon from the point of view of language. Sounds embodied in music, in solitons of nature (the noise of a wave, rustling of foliage, the sound of rain, a crunch of frost, howling of wind, rolling thunder, etc.), as well as in words spoken by a person, structuring into sound streams, create peculiar waves affecting almost all living organisms. This idea was proven in antiquity (using the example of conspiracy and prayer) and is now successfully developing in modern philosophical, psychological and linguistic sciences, in particular, in such areas as neurolinguistic programming, psychoanalysis and suggestive linguistics. These exceptional properties of sounds and the lexemes that form them are well known to people involved in politics, advertising, show business, and working in the field of education; they are successfully used in family education, in interpersonal communication, gender interaction, in medicine; their influence is interesting to those who wish to achieve perfection in spiritual life, develop intuition, and build correct relationships with others. It can be assumed that the

\footnotetext{
* Corresponding author: olganikolenko15011977@gmail.com
} 
sound waves that form lexemes, syntaxemes and higher-level units are a kind of commands that launch positive or negative psycho-biological programs.

\section{Materials and methods}

The fundamental within the framework of the proposed research are descriptive and discursive methods, including the technique of observation, interpretation, comparison and generalization, which make it possible to describe the specific features of the suggestion, as well as the synchronization and diachronization of the analysis of linguistic and scientific facts. The general scientific research methods are the methods of comparative, logical and statistical analysis, systematization of empirical and theoretical data.

\section{Results}

It seems that no one will question the fact that the main condition for a successful human life is good health and social realization, however, widespread negative phenomena upset the balance between soul and body, and then a person turns to higher powers for help, believing that sincerely a spoken phrase directed to them can help in recovery, in establishing interpersonal connections, in improving material well-being or in self-improvement. In this regard, in the last decades, various methods of manipulative intervention in the sphere of the subconscious collective and the individual individual have become quite widespread in esoteric and parapsychological literature, the media, in courses and seminars on personal improvement.

Naturally, such a turn of society towards the "supernatural" could not be ignored by linguistic science, which is recognized to describe linguistic phenomena occurring in society. Taking this into account, linguistic scientists increasingly direct their gaze to the study of the structural and lexical-semantic features of suggestive texts, among which, in the framework of this work, we have identified prayers, healing conspiracies, neurolinguistic programming and affirmations and set ourselves the task of giving them a comparative characteristic with an emphasis on psycholinguistic parameters.

In order to avoid scientific understatement, we will offer definitions for each linguistic definition indicated above.

In the Explanatory Dictionary of the Russian Language S.I. Ozhegov's lexeme "prayer" is defined as "an established canonical text pronounced when addressing God, to the saints." In addition, the dictionary entry provides, in our opinion, a rather interesting example of the contextual use of the analyzed term: to questions Как поживаете? Как Ваше здоровье? the answer is given - Вашими молитвами! From which the conclusion is that prayer helps a person through suggestion or self-suggestion to improve the quality of life.

By a conspiracy we mean a verbalized image that, according to religious beliefs, has a suggestive property due to a special communicative marking of linguistic and syntactic signs, built according to a special model of the deployment of content and form that contributes to the best solution of a suggestive task [9].

"Neuro" is a stereotype, a form of thinking, a subject's understanding of the world that arose during his interaction with other members of society. Neuro-linguistic programming is based on the knowledge of linguistics, psychology and psychotherapy and is guided by the principles of reading and replicating linguistic and / or extra-linguistic forms of behavior of individuals who are successful in a particular area.

An affirmation is an extremely positive statement, a structurally small-volume, but meaningfully capacious phrase with a touch of suggestion or self-hypnosis (autosuggestion), 
correcting the psychological mood of an individual, verbally launching a program aimed at forming in his subconsciousness a positive scenery that normalizes psycho-emotional state.

We see that all definitions have more similarities than differences in their interpretation. By correlating this meaningful definitive content with modern scientific linguistic thought, let us consider the practical side of the suggestive embodiment of each linguistic phenomenon indicated above.

We will be the first to describe the structural and semantic features of the sacred text using the example of a prayer for health addressed to God.

Господи, Создатель наш, помощи Твоей прошу, даруй полное выздоровление Божьей рабе (имя), омой кровушку ее лучами своими. Подари ее телу здравие, ее душе - легкость благословенную, ее сердиу - божественный Твой бальзам. Боль навсегда отступит и сильк к ней вернутся, раны все заживут и придет помощь святая Твоя. Господь, слава Тебе. Аминь!

Note that the text of the prayer begins with an introduction addressed to the higher powers. (Господи, Создатель наш), where one can trace their complete acceptance, faith in them and obedience to them (Божьей рабе). With the verbs used in the imperative mood, the prayer sets out in detail his request (grant, wash, donate) and is filled with complete confidence in the implementation of the above, which proves the indicative mood of the predicates (боль отступит, силь вернутся, раны заживут, придет помощь святая Твоя). In the concluding part of the prayer, the speaker gives praise to God (Господь, слава Тебе), fixes it with the word "Amen", thus sending his request to the Creator.

Each sign of prayer is designed to perform an influencing function: starting from the phonetic level and ending with a special syntactic structure.

The practical conclusions of researchers, whose activities are related to the study of phonosemantics, allow us to assert that the vowel sounds [a], [and] and the letter "e" cause the addressee a feeling of light and bright, and [s] - gloomy and dark; [o] adds volume to the entire phrase; most voiced and plosive consonants convey the dynamics of strength, and [1] and $[\mathrm{m}]$ - melodiousness and tenderness.

If we apply these data to the prayer presented above, then we can see that among the vowels in it prevail [a] and [o] ie sounds and letters that form a bright image of the person to whom the request is directed, and there is practically no root [s]. In the appeal to higher powers and the transmission of admiration for them among the consonants, it is involved in the sound [1]: (Создатель, лучи, сила, славаIn other words, phonemic accentuation as part of a certain segment wraps the word in an expressive shell that covers the entire phrase with a meaningful veil [5].

Combining sounds and letters in words, they move to the second level of suggestion, which involves, in addition to the external meaning of the lexeme, its background content. Let us explain what has been said with examples:

Подари телу здравие, душе - легкость благословенную, ее сердиу - божественный Твой бальзам.

Expressions «легкость благословенная» and «Божественный бальзам» not only a beautiful metaphor: for a Russian person, they have a sacred meaning and mean help from the Creator.

At the syntactic level, the rhythm is created by emphases, a term of expressive syntax that fixes the attention of its addressee on the informational area of speech by placing subjective accents, where the successively described events are presented in a separate narrative frame [6]:

Господи, // Создатель наш, // помощи Твоей прошу.

A healing conspiracy (as well as prayer), as a rule, begins with a sacred introduction addressed to higher powers; smoothly passes to the affirmation of a close connection between man and nature, its elements, capable of connecting the real and imaginary worlds. 
Then the speaker sets out his request in detail and fixes it with a prayer with full confidence in the implementation of the stated:

Стану раба Божья, благословясь, пойду, перекрестясь, пойду я в чистое поле, в чистом поле стоит береза белая, кудрявая. Я поклонюси, помолюси, попрошу истинного Христа батюшку, Матушку пресвятую Богородииу, чтобы у меня никогда бы не скомкнуло, никогда бы не болело - ни в каких мозгах, ни в каких ростах, ни в алой крови, ни на гладкой коже. Отныне до веки веков. Аминь.

It is known that the perception of an individual word is based, firstly, on the understanding of its lexical, and, secondly, on the phonosemantic meaning. It is the semantics of sound in the conspiracy that, through certain sound repetitions, encodes the information transmitted by the conceptual apparatus of the lexeme, sets the emotional-evaluative background in the subconscious of its recipient, creates a certain motivation for correcting perception. The signs of the language act as a verbal code for the implementation of not only real, but also surreal reality [4], so in a certain way, the built-up frequency of repetitive sounds gives the conspiracy a suggestive character.

Let us dwell on the structural and semantic interpretation of the linguistic units that make up the text of the conspiracy.

Expression «чистое поле» means help from nature (in which the seme "genus" is easily visible) before the enemy in the face of the disease. I.e, пойти в чистое поле - means to merge with nature, to become a part of it and be filled with the force of the family, helping to defeat the disease. The birch tree (white birch, curly) often figured in medicinal conspiracies. According to the ideas of our ancestors, it was a connecting link between reality and navu, i.e. real and invisible, between heaven and earth. Therefore, they asked for help from the birch, sometimes they passed on illness to her, believing that both the divine and the devil were contained in it.

The suggestive power of a therapeutic conspiracy (as well as in prayer) at the phonosemantic and lexical levels is realized with greater power if the context is built on the repetition of significant components, the expansion of their characteristics, actualizing the background meaning of the core lexeme and taking into account the anti-mony "language and thinking" , "Language and speech":

Пойду я в чистое поле, в чистом поле стоит береза белая, кудрявая.

The repetition of the phrase "open field" draws attention to the meaningful part of the utterance, and the epithets "white and curly" expand the information content of the accent word "birch" rhythm and melody:

Чтобы у меня никогда бы // не скомкнуло, никогда бы // не болело.

Strengthening the importance of emphatic elements, built according to the type of enumeration, fills the statement with dynamics, musicality, rhythm, which makes them active in the language of folklore. The speech combinations of an individual, spoken aloud or scrolled in thoughts, are instantly responded to by the emotional side, which serves as a veil of the meaningful capacity of the phrase and carries a significant psychological load. This proves that in speech embodiment, the word is capable of performing an additional emotional function. And if it is immersed in a text built according to a certain code, then it is a programming one. Therefore, people who study and apply methods of neurolinguistic programming argue that replacing negative speech patterns with positive ones can activate the subject's internal resources. Programming, using special psycholinguistic programs, inspires the recipient with the idea that he is able to independently manage his life: Everything is in your hands.

Neuro-linguistic programming directs the mental activity and behavioral responses of the individual into the mainstream of tactics that help to choose a solution that is beneficial to the suggestor, through certain strategies, the main of which are speech (phonetic, lexical, structural-grammatical). 
Let's present each of them in the table.

Table 1. Phonetic Suggestors.

\begin{tabular}{|c|l|l|}
\hline \multicolumn{1}{|c|}{ Suggestor } & \multicolumn{1}{|c|}{ Example } & \multicolumn{1}{c|}{ Function } \\
\hline Alliteration & Your cat would buy "Whiskas" & $\begin{array}{l}\text { Repetition of the same } \\
\text { sounds gives volume to } \\
\text { the statement and helps } \\
\text { to better memorize. }\end{array}$ \\
\hline
\end{tabular}

Table 1 proves that sounds of the same type, merging in unison with the intonation pattern of the entire phrase, contributes to better memorization of the meaningful filling of the entire phrase and gently calls for the performance of the action desired by the suggestor.

Table 2. Lexical Suggestors.

\begin{tabular}{|l|l|l|}
\hline \multicolumn{1}{|c|}{ Suggestor } & \multicolumn{1}{|c|}{ Example } & \multicolumn{1}{c|}{ Function } \\
\hline Pronouns & $\begin{array}{l}\text { Everyone will be happy } \\
\text { This medicine will help everyone }\end{array}$ & $\begin{array}{l}\text { Introduces a generalizing } \\
\text { meaning, collectivity, } \\
\text { eliminates the possibility } \\
\text { of a different choice in } \\
\text { actions. }\end{array}$ \\
\hline $\begin{array}{l}\text { Truisms (an } \\
\text { unproven assertion } \\
\text { perceived to be true) }\end{array}$ & $\begin{array}{l}\text { Humans tend to make mistakes } \\
\text { Love for all ages }\end{array}$ & $\begin{array}{l}\text { Affirmative phrases do } \\
\text { not make the suggestant } \\
\text { want to argue, thereby } \\
\text { controlling his attention. }\end{array}$ \\
\hline
\end{tabular}

Table 2 gives reason to believe that the semantic veils of a particular word serve a suggestive effect that extends to the entire utterance.

Table 3. Structural-grammatical suggestors.

\begin{tabular}{|l|l|l|}
\hline \multicolumn{1}{|c|}{ Suggestor } & \multicolumn{1}{|c|}{ Example } & \multicolumn{1}{|c|}{ Function } \\
\hline $\begin{array}{l}\text { Comparative } \\
\text { constructs }\end{array}$ & $\begin{array}{l}\text { The better you relate to others, the easier it } \\
\text { will be for you to live. }\end{array}$ & $\begin{array}{l}\text { The first part of the } \\
\text { statement prompts its } \\
\text { addressee to action, the } \\
\text { second motivates him. }\end{array}$ \\
\hline Rhetorical questions & Is it really possible to live on one salary? & $\begin{array}{l}\text { It not only establishes a } \\
\text { fact, but also convinces } \\
\text { the object of speech to } \\
\text { change something in his } \\
\text { life. }\end{array}$ \\
\hline Double questions & $\begin{array}{l}\text { Will you wash the dishes right away or take } \\
\text { out the trash first? } \\
\text { Have you noticed that rich people are } \\
\text { stingy? }\end{array}$ & $\begin{array}{l}\text { One } \\
\text { disjointed phrase has two } \\
\text { questions. The first part } \\
\text { acts as an auxiliary } \\
\text { inspiring element, the } \\
\text { second is already } \\
\text { intuitively regarded as } \\
\text { truth. }\end{array}$ \\
\hline
\end{tabular}

Table 3 shows that the linguistic material in texts with neurolinguistic programming is quite diverse, but its use is aimed at one goal: to form an altered holistic picture in the recipient's mind.

Almost every person perceives the events taking place through the prism of emotions [3]. And what emotions are priority depends on his emotional, spiritual and, as a result, his physical condition. According to psychoanalysts, affirmations help to change the attitude to the picture of the world. The linguistic essence of the issue of these suggestive texts is 
reduced to the introduction of specially selected keywords in them, which play the main role for a specific individual:

Life loves you!

Your world cares about you!

People perceive the world around them mainly visually and convey their ideas about it also in visual images by means of words. The essence of suggestion through affirmation consists in influencing the feelings of a person, and through them on all his will and mind in order to create a certain state or inducement to planned actions [8].

Consequently, through affirmation, a system of connections "image - concept" is formed in our consciousness, that is, everything seen corresponds to some kind of verbal description, caused by the most diverse associations.

Thinking about this or that object or phenomenon, pronouncing this or that phrase, a person creates images, pictures, perceives them, and then forms an attitude towards their content.

\section{Discussion}

The conclusions made in the framework of this study do not claim to be exclusive; they only expand and supplement the existing knowledge provided after a certain cycle of proofs by such sciences as:

1. Psychology (works of G. Popovkina, V. Zusman, O. Zuga, S. Zlivko, describing technologies for changing beliefs and healing using neurolinguistic programming, prayers and conspiracies) $[10,13,14]$;

2. Philosophy (studies by T. Brunfaut, L. Harding, A. Batty and others, where a comparative analysis of the main suggestive techniques (including affirmations and prayers) is undertaken $[2,15,16]$;

3. Linguistics (V. Chekmarev, V. Zinatullin, E. and others, who direct their scientific view to the study of structural and lexical-semantic features of suggestive texts) $[4,12,7]$.

The works indicated above investigate the issues of a non-generalized definitive concept in the mainstream of concrete science; This work attempts to describe from different angles suggestion as a linguistic phenomenon.

\section{Conclusion}

Based on the action of the mechanism of suggestion and self-hypnosis through prayer, conspiracy, neurolinguistic programming and affirmations, a person is able to change the stereotype of thinking and, therefore, behavior, because he is filled with faith in his own strengths and capabilities. Positive suggestion forms positive impulses for the transformation of word forms and mental images into a working tool of the subconscious with the aim of transforming thoughts into a physical shell. In other words, each individual throughout his life involuntarily or intentionally verbally or non-verbally programs both his subconscious and the subconscious of a real or virtual interlocutor. A phrase compiled according to a certain principle allows its addressee to introduce the desired thought into the recipient's subconscious, adjust it to a predetermined landmark, formalize his self-awareness, thereby restoring (or destroying) physical and / or spiritual integrity.

Please note that the first paragraph of a section or subsection is not indented. The first paragraphs that follows a table, figure, equation etc. does not have an indent, either.

Subsequent paragraphs, however, are indented. 


\section{References}

1. Borisova, E.: Reflection of the communicative organization of an utterance in the lexical meaning. Questions of linguistics 2, 113-121 (2011)

2. Brunfaut, T., Harding, L., Batty, A.: The effect of mode of delivery on performances and perceptions on an English L2 writing test suite. Assessing Writing, 36, 3-18 (2018).

3. Strickland, B., Fisher, M., Keil, F., Knobe, J.: Syntax and intentionality: An automatic link between language and theory-of-mind, Cognition, 1, 249-261 (2014)

4. Chekmarev, V.: Technology of mechanical engineering: a short course of lectures for students of the third year of the direction of preparation Agroengineering, 58 (2018) (in Russ)

5. Ferguson, G., Perez-Llantada, C., Pio, R.: English as an International Language of Scientific Publication: A Study of Attitudes World Englishes 30, 41-59 (2011) DOI: 10.1111/j.1467-971X.2010.01656.x

6. Chater, N., Stewart, M.: Language as skill: Intertwining comprehension and production, Journal of Memory and Language, 89, 244-254 (2016)

7. Downey, R., Farhady, H., Present-Thomas, R., Suzuki, M.: Evaluation of the usefulness of the Versant for English test: A response. Language Assessment Quarterly 5(2), 160 111 (2018). DOI: 10.1080/15434300801934744

8. Nikolenko, O., Belozerova, A., Sumina, N., and Shapovalova, E.: Parcelled phrases in the aspect of business communication Breakthrough Technologies and Communications in Industry. International Scientific Practical Conference. Volgograd, Russian Federation, 673 (2018) DOI: 10.1051/shsconf/20196900081

9. Nikolenko, O., Zakharchuk O., Babakova, L., and Morenko, B.: The 'I' of the author and its persuasive function (as exemplified by the complex sentence with homogeneously collateral sub clauses). The International Scientific and Practical Conference Current Issues of Linguistics and Didactics: The Interdisciplinary Approach in Humanities and Social Sciences 69, 00081 (2019) DOI:1051/shsconf/20196900081

10. Nikolenko, O., Shapovalova, E., Malina, N.: Emphasis in poetic phrase as a suggestion tool. International Scientific Forum «National Interest, National Identity and National Security» 269-273 (2021) DOI: 10.15405/epsbs.2021.02.02.87

11. Popovkina, G.: Problems of typology of folk medicine of the Eastern Slavs, Russia 2, 81-87 (2012).

12. Sokur, I.: Lexical and stylistic originality of phraseological units in a scientific text. Corporate research of Slavic languages and literatures. In memory of academician Leonid Bulakhovsky, Moscow, 12 (2010).

13. Zinatullin, V., Chibisova, E.: Emphasis in English scientific literature: ways of expression and principles of translation. Philological sciences. Questions of theory and practice 2 (4), 129-133 (2011).

14. Zusman, V.: Concept in the system of humanitarian studies 2, 3-29 (2013).

15. Zuga, O., Zlivko, S.: On the problem of describing phraseological units in scientific and academic texts (based on the works of Russian linguists). In the world of scientific discovery (2014).

16. Varzonin, Yu.: A rhetorical model: worldview, ethics, communication. Language, culture and society in the humanitarian paradigm: A collection of papers. Moscow, 7-12 (2015). 